JOURNAL of

CONTEMPORARY INDONESIAN

ART

Jurusan Seni Murni

FSR ISI Yogyakarta

ISSN: 2442-3394

E-ISSN: 2442-3637

\section{PENGEMBANGAN SCRAPBOOK SEBAGAI MEDIA KARYA KREATIF DAN ART THERAPY}

Yemima Yoke Handakara

Kriya Logam, Penciptaan Seni, Pascasarjana ISI Yogyakarya, J1. Suryodiningratan No.8, Suryodiningratan, Kec. Mantrijeron, Kota Yogyakarta, Daerah Istimewa Yogyakarta

Email: isabellayemima@gmail.com

\begin{abstract}
Abstrak
Pandemi virus Corona (COVID-19) yang berkepanjangan membuat masyarakat merasa jenuh dan bosan. Adanya kebijakan Work From Home (WFH) membuat masyarakat mau tidak mau membatasi ruang gerak mereka. Keadaan perekonomian masyarakat yang terpuruk juga membuat keadaan menjadi semakin sulit bagi kebanyakan orang. Satu per satu tren kreatif sebagai ungkapan menghibur diri bermunculan. Salah satunya scrapbook yang bukan hanya sebagai media pengasah kreatifitas, tetapi juga bisa menjadi media menulis (diary). Penelitian ini memiliki tujuan untuk membuat kreasi scrapbook sebagai media kreasi sekaligus sebagai alat art therapy. Penelitian yang dilakukan menggunakan metode pendekatan estetika dan metode penelitian Practice Based Research.

Kata Kunci : Scrapbook, Karya Seni, Kreatif, Media, Art Therapy.
\end{abstract}

\begin{abstract}
The prolonged Corona virus (COVID-19) pandemic has made people feel bored and bored. The existence of the Work From Home (WFH) Policy has made people not want to limit their space. The deteriorating state of the community's economy also made things even more difficult for most people. One by one, creative trends as expressions of self-entertainment emerge. One of them is scrapbook, which is not only a creative media sharpener, but also a written media (diary). This research aims to make scrapbook creations as a creative medium as a therapeutic art tool. The research was conducted using an aesthetic approach and practical research based research methods.
\end{abstract}

Keywords: Scrapbook, Artwork, Creative, Media, Art Therapy. 


\section{A. Pendahuluan}

Pandemi virus Corona (COVID19) yang merebak dari provinsi Wuhan China, telah menginfeksi lebih dari 120 juta otang di seluruh dunia. Data ini diambil berdasarkan situs worldometers.info per tanggal 15 Maret 2020 yang dipantau secara realtime (worldometer). Sejak tanggal 11 Maret 2020, Organisasi Kesehatan Dunia (WHO) menetapkan wabah virus Corona sebagai pandemi global. Untuk menyikapi keputusan WHO, Presiden Republik Indonesia, Joko Widodo, melalui Konferensi Pers di Bogor pada tanggal 15 Maret 2020 menghimbau kepada seluruh masyarakat Indonesia untuk bekerja, sekolah, dan beribadah di rumah demi mencegah penyebaran virus Corona. Mengikuti pernyataan dari bapak Presiden, Kementerian Keuangan juga mulai menerapkan kebijakan Work From Home (WFH) yang kemudian menjadi pedoman masyarakat dalam melakukan kegiatan sehari-hari (Kementerian Keuangan, 2020).

Kegiatan Work From Home (WFH) dan School From Home untuk anak sekolah, membuat bagi sebagian orang memiliki waktu luang yang lebih. Di awali dengan banyak nya waktu luang dan mengusir rasa bosan, tren-tren kreasi kreativitas mulai bermunculan. Satu per satu tren kegiatan maupun kreativitas munculan sepanjang 1 tahun pandemi Corona demi menghibur diri dan orang lain. Mulai dari tren olahraga, seperti bersepeda. Trend kreasi makanan dan minuman, seperti dalgona (kopi), cloud bread, dessert boc, Korean garlic bread, sei sapi (Kompas.com, 2020). Tren bercocok tanam, seperti hidroponik dan tanaman hias. Bahkan hingga tren kreativitas seperti tiktok, saling berkirim hampers (hantaran / kado), melukis, dan scrapbook.

Meski bukan hal baru di Indonesia, eksistensi scrapbook kembali naik daun dan populer 1 tahun terakhir ini. Padahal sebenarnya di Indonesia, scrapbook populer kurang lebih 10 tahun terakhir ini (Christiyanti, 2016). Namun meskipun sudah masuk ke Indonesia 10 tahun yang lalu, ternyata masih banyak masyarakat kurang akrab dengan istilah scrapbook.

Scrapbook mulai popular di Inggris Raya pada abad ke-15. Pada abad ini, seni menempel ini biasanya digunakan untuk menulis resep makanan, kutipan surat, dan banyak hal lainnya. Pada abad ke-16, mulai muncul tren album persahabatan. Album ini memiliki wujud seperti buku tahunan yang modern, dimana pemilik dapat memasukkan judul, nama, dan juga teks singkat sesuai keinginan. Pada tahun 1775, James Granger menerbitkan buku yang memiliki beberapa halaman kosong pada bagian akhir buku.

Halaman-halaman ini sengaja dirancang kosong untuk memungkinkan pemilik buku memiliki ruang kosong untuk berkreasi seperti menempelkan litografi, ilustrasi, ukiran, bahkan membongkar atau memasukkan materi baru. Selanjutnya, album pertemanan dan buku tahunan populer pada abad ke 18 dan 19. Tren untuk saling berbagi keterampilan bersastra membuat anak-anak perempuan pada masa itu berlomba untuk mendokumentasikan catatan pribadi mereka sendiri.

Selama abad ke-19, scrapbooking dipandang sebagai cara yang ramah lingkungan dan mampu menyimpan kenangan lebih baik dibanding membuat jurnal berbentuk tulisan lainnya. Materimateri cetak seperti koran, kartu kunjungan / tiket, dan pamflet beredar luas selama abad ke-19. Materi-materi ini sering kali menjadi bahan utama dalam pembuatan scrapbook pada masa itu ("scrapbooking", 2020). Dalam bahasa Inggris, scrap memiliki arti barang sisa. Sedangkan scrapbook sendiri merupakan kegiatan menempel dan menghias media, bisa berupa kertas atau foto menjadi karya kreatif yang memiliki muatan seni. (Kompas.com, 2010)

Pada dasarnya, scrapbook adalah kegiatan untuk melestarikan dan menyusun kenangan seperti foto dan tulisan ke dalam bentuk buku, kotak, atau kartu (Kompas.com, 2010). Pembuatan scrapbook membutuhkan kreativitas dan kepekaan seni, hal ini disebabkan karena ketika dalam menyusun scrapbook, kreator diharuskan untuk memikirkan tata letak dari komponen yang akan digunakan hingga menghasilkan perpaduan letak, warna, bentuk, dan atau tema tertentu. Scrapbook menjadi media untuk menuangkan kreativitas berkesenian. Kata seni sendiri dalam KBBI (2016) 
memiliki arti keahlian membuat karya yang bermutu, karya yang diciptakan dengan keahlian yang luar biasa. Dalam (Sahman, 1993) mengatakan bahwa seni dapat dilihat sebagai sebuah aktivitas mengungkapkan perasaan atau emosi dari penciptanya, sehingga karya yang dihasilkan memiliki karakteristik yang mencerminkan kehidupan perasaan penciptaannya (Andono \& Rispul, 2016, hal. 61).

Menurut Joseph Kosuth seorang tokoh dari gerakan Conceptual Art yang muncul di Amerika tahun 1960 an, suatu karya bisa dinamakan seni jika memenuhi 3 syarat :

1. Membuat orang bertanya-tanya mengenai apakah ini seni atau bukan

2. Karya tersebut dipasang di area publik

3. Kreator memberikan klaim jika karya nya adalah seni (Marianto, 2021). Sehingga karya scrapbook juga bisa digolongkan kedalam karya seni kriya.

Menurut (Rispul, 2012), Seni Kriya memiliki arti sesuatu yang dikerjakan yang melibatkan kemampuan dan keahlian tangan secara terampil, dekoratif, memiliki visual artistik meski memiliki fungsi praktis atau memiliki fungsi daya guna. Seni kriya menjadi tidak dihargai oleh masyarakat jika didalamnya tidak disertai dengan faktor kreativitas, inovatif, keunikan sebagai hasil eksplorasi ide dan bahan. Dalam penciptaan seni kriya, sangat membutuhkan kekriyaan (craftsmanship) yang tinggi, ketangkasan teknik dari kreatornya (virtuositas), dan mengikuti perkembangan jaman. Sehingga produk seni kriya tidak hanya sekedar memenuhi kebutuhan praktis tetapi juga memenuhi tujuan ekspresif dari pembuatnya.

Selain itu, berkreasi pada scrapbook juga bisa menjadi art therapy bagi sebagian orang sekaligus mengasah kreatifitas dalam membuat karya. Menurut Naumberg dalam What is Art Therapy? In Dynamically Oriented Art Therapy (2004) Art Therapy pertama kali digunakan oleh Adrian Hill, seorang seniman dari Inggris. Hill mengungkapkan bahwa nilai dari Art Therapy : "Completely engrossing the mind (as well as the fingers) ... [and in] releasing the creative energy of the frequently inhibited patient". Kemudian di tahun yang sama, Margaret Namberg, seorang psikolog, juga mulai menggunakan istilah Art Therapy dalam prakteknya. Dari sinilah kemudian Art Therapy mulai berkembang (Aiyuda, 2019, hal. 149-150).

Menurut Serlin (2007), seni dianggap mampu menyentuh dan juga bisa mengungkapkan kompleksitas manusia termasuk tingkat pikiran, tubuh, dan jiwa. Selain itu, berdasarkan studi menunjukkan bahwa seni dapat mengurangi kelihan stress dan kesehatan, meningkatkan fungsi kekebalan tubuh, memberikan manfaat fisik dan psikologis, bahkan membantu orangorang untuk hidup lebih lama (Aiyuda, 2019). Dalam American Art Therapy Association (2013), The American Art Therapy Association mendefinisikan Art Therapy sebagai terapi yang menggunakan seni, dalam hubungan professional, pada orang-orang yang memiliki trauma, penyakit, tantangan dalam hidup atau oleh orang-orang yang mencari pengembangan pribadi. Melalui penciptaan seni, merefleksikan seni dan prosesnya, orang dapat meningkatkan kesadaran diri dan orang lain, mengatasi gejala stress dan pengalaman traumatis, meningkatkan kemampuan kognitif, dan menikmati kesenangan dalam seni (Aiyuda, 2019, hal. 155-156). Lalu, Arnheim (1969) berpendapat bahwa seni dapat digunakan untuk memfasilitasi penyelesaian masalah yang terjadi (Curl, 2008, hal. 165).

Lubis (2009) berpendapat bahwa depresi merupakan gangguan mental yang kerap terjadi di tengah masyarakat. Awal mula dari depresi adalah adanya stress yang tidak teratasi. Dimana kemudian stress ini dapat berlanjut masuk ke fase depresi (Permatasari et al., 2017, hal. 117).

$$
\text { Menurut Malchiodi }
$$

memberikan pernyataan bahwa art therapy merupakan bentuk terapi yang bersifat ekspresi dengan menggunakan seni seperti kapur, spidol, lukisan, dan lain-lain. Media seni dan proses kreatif dari metode ini bertujuan untuk membantu mengekspresikan diri, membantu mengelola stress dan memperkuat rasa percaya diri. Art therapy dapat diartikan juga sebagai kegiatan membuat karya seni untuk memenuhi kebutuhan psikologis dan emosional individu, baik individu yang 
bersangkutan memiliki kemampuan dalam seni ataupun tidak. Melalui art therapy individu dapat mengungkapkan perasaan yang dialami dengan menggunakan seluruh area atau fungsi dalam diri mereka (Permatasari et al., 2017, hal. 117).

mengenai mengekspresikan diri dan memperkuat rasa percaya diri, pernyataan ini juga didukung oleh pendapat Sugiharto yaitu ketika seseorang menciptakan karya seni yang kreatif, dia juga sedang menciptakan sebuah metafora baru, apakah yang inovatif atau yang menawarkan pembaruan. Poin dan wilayah penting inilah yang akan menumbuhkan rasa percaya diri bagi para seniman, mahasiswa seni, pencipta karya seni (Marianto, 2019, hal. 171).

Bentuk dari art therapy dapat bermacam-macam, salah satunya adalah membuat diary atau buku harian. Dikutip dari kumparan WOMAN (2019) mengatakan bahwa menulis diary memiliki lima manfaat bagi kesehatan mental, yaitu : mindfulness atau berfokus pada apa yang dimiliki saat ini, bisa menyembuhkan luka hati, mengurangi stress dan memperbaiki kesehatan, mempertajam ingatan, dan memperkuat fungsi emosional. Sedangkan dalam artikel hello SEHAT (2020) menuliskan bahwa menulis diary memiliki manfaat seperti membuat si penulis menjadi lebih menyadari diri sendiri, seperti kebiasaan perilaku, maupun evaluasi diri. Menulis diary juga memiliki manfaat baik bagi kesehatan mental, yaitu untuk memperkuat fungsi emosional. Lalu, diary juga bermanfaat baik untuk mengurangi tingkat stress yang sedang dihadapi.

\section{B. Tujuan}

Scrapbook sebagai media berkreasi sekaligus sebagai Art Therapy.

\section{Metode Pendekatan}

Metode pendekatan yang digunakan adalah metode Estetika. Dalam Kamus Lengkap Bahasa Indonesia (1997), estetika adalah ilmu yang membicarakan seluk beluk (p. 163). Istilah Estetika dalam KBBI (2016), estetika adalah cabang filsafat yang menelaah dan membahas tentang seni dan keindahan serta tanggapan manusia terhadapnya, estetika berarti juga kepekaan terhadap seni dan keindahan.

Kehidupan manusia tidak pernah lepas dari peran seni dan estetika/ keindahannya. Seni dapat ditemukan dimanapun, contohnya di rumah, di jalan raya, maupun di kantor atau sekolah. Maka dari itu, estetika menjadi pedoman penting dalam sebuah penciptaan karya seni.

Scrapbook juga merupakan salah satu bentuk karya seni crafting (kriya). Mulai dari menyiapkan bahan, sampai karya jadi, proses pembuatan scrapbook sangat lekat dengan karya tangan atau handmade. Sebagai salah satu karya seni, scrapbook juga tidak lepas dari faktor estetika, Dimana presentasi hasilnya baik dari segi warna, bentuk, dimensi, maupun bahan tentunya lekat dengan estetika.

\section{Metode Penelitian}

Metode penelitian yang digunakan pada penelitian ini adalah Practice-based Research penciptaan berdasarkan penelitian. Ini merupakan metode yang dimulai dari melakukan praktik serta penelitian dengan basis praktik. Kegiatan ini merupakan kajian orisinil yang dilakukan demi memperoleh pengetahuan baru melalui praktik dan hasil yang didapatkan. Penelitian berbasis praktik merupakan penelitian yang lebih sesuai untuk para perancang karena pengetahuan baru yang didapat dari penelitian dapat langsung diterapkan pada bidang yang bersangkutan, dan melakukan yang terbaik menggunakan kemampuan dan pengetahuan yang dimiliki selama prosesnya penelitian dilakukan pada subjek yang diteliti (Malins et al., 1996, hal. $1-2)$. 


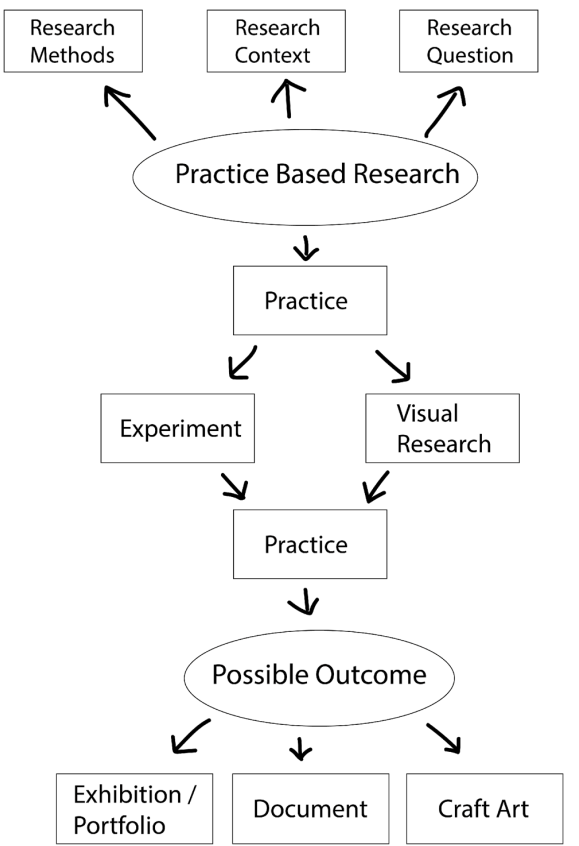

Sumber : skema dokumentasi penulis

Dalam skema konsep practice-based research di atas penulis dapat menyimpulkan penciptaan berbasis penelitian terdiri 3 pilar pokok yang harus dikuasai agar konsep penciptaan yang dibuat berjalan dengan baik.

\section{a. Pilar 1}

Dalam skema konsep practice-based research, terdiri dari 3 research awal yang dilakukan oleh penulis, yaitu :

1) Research Context

Research Context / penelitian konteks adalah latar belakang penciptaan. Dalam proses ini, penulis harus membuat konsep dengan jelas mengenai materi dan konteks permasalahan yang diambil seperti tema, ide, material, bentuk, teknik, dan lainlain.

\section{2) Research Question}

Research Question / pertanyaan penelitian berisi rumusan penciptaan karya. Research question dirumuskan dengan jelas mengenai bentuk karya yang akan diciptakan.

\section{3) Research Methods}

Research Methods / metode penelitian, adalah bagaimana karya dan laporan dapat terciptan dengan hasil yang maksimal.

$$
\text { b. Pilar } 2
$$

Pilar 2 merupakan proses practice / latihan. Pada tahap ini, peneliti atau kreator melakukan tahap practice mengandalkan trial and error. c. Pilar 3

Pilar ke-3 adalah Possible Outcome, dimana pada tahap ini karya yang dihasilkan bisa berupa karya untuk exhibition / pameran / portfolio, document, dan craft art / karya untuk dijual.

\section{E. Pembahasan}

Dikutip dari (Rispul, 2012) produk seni kriya tidak hanya sekedar memenuhi kebutuhan praktis tetapi juga memenuhi tujuan ekspresif dari pembuatnya. Maka, peran scrapbook sebagai media karya kreatif sekaligus sebagai art therapy menjadi relevan. Dimana kreator bisa menumpahkan segala kreativitas dan imajinasi dalam menghias karya.

Scrapbook bisa berfungsi menjadi apa saja. Mulai dari album foto keluarga, hobi dan koleksi, surat-menyurat, bahkan bisa berfungsi juga sebagai diary harian. Proses pembuatan scrapbook tergolong cukup mudah dan menyenangkan karena bisa dilakukan di rumah, dan juga bahanbahannya yang mudah di temukan. Scrapbook juga bisa memanfaatkan bahan bekas (daur ulang) seperti kertas bekas, koran bekas, tiket, kardus bekas, dan bunga kering. Namun, sebelum membuat scrapbook, alangkah baiknya untuk terlebih dahulu merancang atau menentukan gambaran perkiraan hasil jadinya.

\section{Menentukan Tema}

Pertama tentukan tema dari scrapbook, misalnya tema vintage, floral, monokrom, rainbow, simple. Penentuan tema ini mempermudah kreator untuk menentukan bahan yang ingin digunakan, dan juga membantu memberikan gambaran hasil jadi yang diharapkan. Tema ibaratnya guideline yang membantu kreator menentukan garis besar dari segi isi maupun bahan yang digunakan.

Misalnya tema yang dipilih adalah vintage, maka hal pertama yang harus dilakukan kreator adalah melakukan brainstorming dari tema ini. Kreator bisa melakukan riset kecil-kecilan untuk mencari ide dan referensi melalui media sosial seperti Instagram atau pinterest.

\section{Menyiapkan Alat dan Bahan}


Setelah mencari dan mendapat referensi yang dirasa cocok, selanjutnya kreator mulai mempersiapkan alat dan bahan. Alat dan bahan yang dibutuhkan menyesuaikan tema dan kreativitas dari masing-masing kreator.

Misalkan untuk tema vintage, akan cocok jika bahan yang disiapkan adalah kertas surat berwarna coklat alami. Jika kertas surat berwarna coklat alami mungkin sulit dicari, maka bisa digantikan dengan membuat sendiri / DIY (Do It Yourself) dengan kertas HVS yang dicelupkan kedalam kopi atau teh, kemudian dikeringkan. Lalu perangko (bisa perangko bekas maupun baru), lem, foto, stiker, cap dan bahan-bahan lain yang sekiranya cocok dan mendukung. Bisa juga dengan menambahkan herbarium (awetan tumbuhan), atau kertas daur ulang.

\section{Proses Hias}

Setelah alat dan bahan siap, mulailah memotong dan menempel, kemudian susun di atas buku atau kertas yang menjadi alas dasar. Proses ini ibaratnya sedang menyusun puzzle. Kreator dapat berkreasi sekreatif mungkin dengan alat dan bahan yang ada. Tahapan proses hias biasanya memakan waktu yang paling lama dibanding tahap-tahap sebelumnya. Tahapan ini cukup memakan waktu karena kreator harus teliti dan cermat dalam menyusun komponen bahan yang akan dijadikan scrapbook, sehingga hasil yang didapat juga tidak mengecewakan.

Di dalam scrapbook, tentu tidak hanya terdiri dari gambar atau kertas saja, tetapi tidak jarang juga terdapat tulisan. Tulislah apapun yang ingin dituangkan didalamnya. Bisa berupa ungkapan perasaan, keterangan, kutipan favorit, bahkan doa. Scrapbook juga dapat dimanfaatkan sebagai diary atau buku harian.

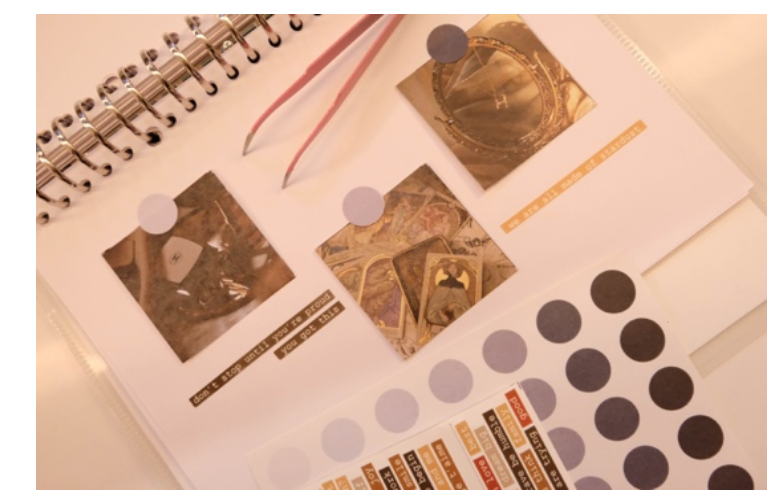

Gambar 1. Hasil scrapbook dengan kalimat motivasi. (Sumber : dokumentasi pribadi, 2021)

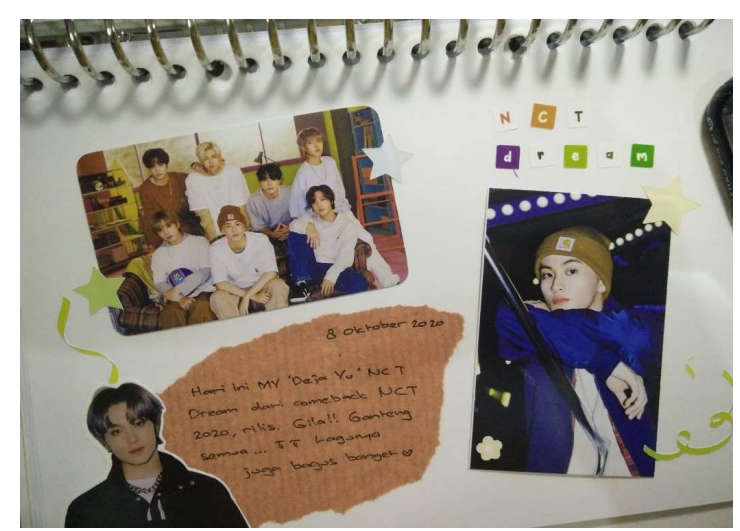

Gambar 2. Hasil scrapbook sebagai diary.

(Sumber : dokumentasi pribadi, 2021)

Ada kalanya akan terasa kurang puas dengan scrapbook yang dihasilkan, tetapi dengan banyaknya latihan membuat scrapbook dengan berbagai variasi (menerapkan metode practice based research) sehingga hasil yang didapat semakin lama semakin baik dan variatif.

\section{F. Kesimpulan}

Bentuk akhir dari scrapbook tidak terbatas pada book / buku saja, tetapi bisa juga berbentuk pigura / scrap frame, packaging cantik, bahkan masih banyak kemungkinan scrapbook bisa dikembangkan menjadi bentuk karya yang lain. Membuat scrapbook juga ibaratnya seperti latihan melukis yang semakin lama semakin berkembang kreatif, dan menghasilkan inovasi kreasi yang baru. Maka dari itu, metode penciptaan practice based research yang menitikberatkan penelitian berbasis latihan atau percobaan dapat terbukti efektif dalam penciptaan karya.

Selama proses pembuatannya, scrapbook juga memiliki pengaruh baik bagi 
psikologis kreatornya. Yaitu sebagai bagian dari Art Therapy dimana kreator dapat menyalurkan kreativitasnya, sebagai hiburan dan relaksasi, sekaligus sebagai buku harian atau diary. Bahkan kreator juga dapat menuliskan kalimat-kalimat positif didalamnya. Sehingga scrapbook bukan hanya sebagai bagian dari hobi, tetapi juga menjadi kegiatan terapi yang menyenangkan, dan kegiatan relaksasi untuk mengurangi stress dari kreatornya. Kegiatan menulis diary yang diiringi dengan kegiatan kreatif seperti menghias tulisan menjadi bentuk scrapbook diharapkan bisa membuat perasaan dan pikiran dari kreator menjadi semakin baik.

Hal ini sejalan dengan pendapat Snyder \& Lopez (2007) yang mengatakan bahwa leisure adalah aktivitas yang dapat menaikkan kepercayaan diri seseorang karena memiliki makna tersendiri bagi orang tersebut, memberikan kebebasan, sarana untuk keluar dari rutinitas sehari-hari, dan sarana untuk bersosialisasi dengan orang lain. Leisure diartikan sebagai bagaimana seorang individu memanfaatkan waktu luangnya, apa yang dilakukan untuk berelaksasi, aktivitas yang dilakukan untuk memperoleh kesenangan, dan bagaimana menyalurkan hasrat dan minat (Shokiyah \& Syamsiar, 2019, hal. 38).

Maka dari itu, seseorang dapat memanfaatkan scrapbook sebagai bagian dari leisure mereka sekaligus sebagai art therapy untuk menurunkan tingkat stress.

\section{DAFTAR PUSTAKA}

Aiyuda, N. (2019). Art therapy. Nathiqiyyah, 2(1).

Andono, A., \& Rispul, R. (2016). Eksplorasi Dan Eksperimentasi Dalam Karya Seni Kriya Kontemporer. Corak: Jurnal Seni Kriya, 5(1).

Christiyanti, A. (2016). PEMANFAATAN LIMBAH PADAT MENJADI SCRAPBOOK MELALUI BRAINSTROMING. Unika Soegijapranata.

Curl, K. (2008). Assessing stress reduction as a function of artistic creation and cognitive focus. Art Therapy, 25(4), 164169.

Malins, J., Ure, J., \& Gray, C. (1996). The gap: Addressing practice-based research training requirements for designers. The Robert University, Aberdeen, United Kingdom.

Marianto, M. D. (2019). Seni dan Daya Hidup Dalam Perspektif Quantum. Scritto books \& BP ISI Yogyakarta.

Permatasari, A. E., Marat, S., \& Suparman, M. Y. (2017). Penerapan art therapy untuk menurunkan depresi pada lansia di Panti Werdha X. Jurnal Muara Ilmu Sosial, Humaniora, dan Seni, 1(1), 116-126.

Rispul, R. (2012). Seni Kriya Antara Tekhnik Dan Ekspresi. Corak: Jurnal Seni Kriya, 1(1).

Sahman, H. (1993). Mengenali Dunia Seni Rupa. Semarang: IKIP Semarang Press.

Shokiyah, N. N., \& Syamsiar, S. (2019). TERAPI MELUKIS UNTUK MEMBANTU MENURUNKAN DEPRESI PADA REMAJA.

\section{Website:}

helloSEHAT. (2020, Jun 07). 3 Manfaat Menulis Jurnal untuk Kesehatan Mental dan Cara

Memulainya. Retrieved from https://hellosehat.com/mental/stres / manfaat-

menulis-jurnal-mental/

KBBI daring. (2016). Seni. Mar 16, 2020. Retrieved from https://kbbi.kemdikbud. go.id/entri/seni

KBBI daring. (2016). Estetika. Mar 16, 2020. Retrieved from https://kbbi. kemdikbud.go.id/entri/estetika

Kementerian Keuangan. (2020). COVID-19, Work From Home. Retrieved from https://www.djkn.kemenkeu.go.id/kp knl-parepare/bacaartikel/ 13058/COVID19-Work-From-Home-dan-RevolusiIndustri-40.html

Kompas.com. (2020, Aug 16). 12 Produk Makanan yang Jadi Tren pada Masa Pandemi. Retrieved from https://www.kompas.com/food/read/ 2020/08/16/210900075/12-produkmakanan-yang-jadi-tren-pada-masapandemi-ide-jualan-online? page $=$ all 
Kompas.com. (2010, May 14). Scrapbook, Bukan Sekedar Menempel Barang Sisa. Retrieved from https: / / lifestyle.kompas.com/read/20 10/05/14/16021381/scrapbook.buka n.sekadar.menempel.barang.sisa

KumparanWOMAN. (2019, Nov 12). 5 Manfaat Menulis Buku Harian bagi Kesehatan Mental. Retrieved from https: / / kumparan.com/kumparanwo man/5-manfaat-menulis-buku-harianbagi-kesehatanmenta1sEqxE37tf1/full

Marianto, M. D. (2021). Gerakan Conceptual Art [Paper presented at lecture for class Kritik Seni]. Pascasarjana ISI Yogyakarta.

Scrapbooking. (2020). Retrieved Mar 16, 2020 from https://en.wikipedia.org/ wiki/Scrapbooking

Worldometer. (2020). COVID-19 CORONAVIRUS PANDEMIC. Retrieved from

https: / ftp.worldometers.info/coronavi rus / 